\title{
Trans-acting factors from the human fetal liver binding to the human $\varepsilon$-globin gene silencer
}

\author{
YAN ZHI JIANG, CHU JIANG, RUO LAN QIAN ${ }^{1}$ \\ Shanghai Institute of Cell Biology, Chinese Academy of \\ Sciences, Shanghai 200031, China
}

\begin{abstract}
The developmental stage-specific silencing of the human $\varepsilon$-globin gene during embryonic life is controlled, in part, by the silencer $(-392 \mathrm{bp} \sim-177 \mathrm{bp})$ upstream of this gene. In order to elucidate its role, the nuclear extract from the human fetal liver has been prepared and the interactions between trans-acting factors and this silencer element have been examined. By using DNaseI footprinting assay, a major protected region from $-278 b p$ to $-235 b p$ within this silencer element was identified. Furthermore, we found in gel mobility shift assay and Southwestern blotting assay that there were at least four trans-acting factors $(\mathrm{MW} \approx 32,28,26$ and $22 \mathrm{kD}$ ) in the nuclear extract isolated from the human fetal liver, which could specifically bind to this region. Our results suggested that these trans-acting factors might play an important role in silencing the human embryonic $\varepsilon$-globin gene expression at the fetal stage through the interactions with this silencer.
\end{abstract}

Key words: Human $\varepsilon$-globin gene, silencer, transacting factor.

\section{INTRODUCTION}

The human embryonic $\varepsilon$-globin gene is a member of the $\beta$-like globin gene family. This gene is expressed in a tissue-specific and developmental stage-specific manner. During early embryonic life, the human $\varepsilon$-globin gene is expressed at high level in the blood island of yolk sac but is silenced completely at 6-8 weeks of gestation in

1. To whom correspondence should be addressed: Shanghai Institute of Cell Biology, Chinese Academy of Seiences, 320 Yue-yang Road, Shanghai 200031, China. 
DNA-protein interaction in the human $\varepsilon$-globin gene silencer

the fetal liver. Elucidation of the molecular mechanisms that control the silencing of the human $\varepsilon$-globin gene expression at later developmental stages is important since the reactivation of this gene in individuals with sick cell anemia and $\beta$-thalassemia can potentially cure these anemias[1]. Studies on transgenic mice have shown that the cis sequences that direct the developmental silencing of the human $\varepsilon$-globin gene expression are located near this gene[2, 3]. In fact, a transcriptional silencer (between -392bp and -177bp) upstream of the human $\varepsilon$-globin gene has been identified by transient transfection of deleted $\varepsilon$-globin gene constructs into HeLa and K562 cells[4] (Fig 1). Deletion of this sequence results in the continued expression of the human $\varepsilon$-globin gene during late fetal and adult development in transgenic mice, suggesting that in vivo this silencer may play a critical role in silencing the human embryonic $\varepsilon$-globin gene at these later developmental stages[5].

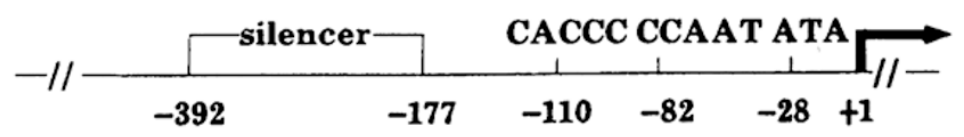

Fig 1. The diagram of the upstream region of the human $\varepsilon$-globin gene. The positions of the TATA(ATA), CCAAT and CACCC sites of the constitutive promoter, as well as the silencer element are shown. Sequence numbering corresponds to the cap site at +1 .

In this study, DNaseI footprinting assay, gel mobility shift assay and Southwestern blotting assay were carried out and at least four trans-acting factors capable of binding to this silencer element were identified in the nuclear extract from the human fetal liver, in which the human embryonic $\varepsilon$-globin gene was completely silenced. Our data demonstrated that these trans-acting factors might play an important role in silencing the human embryonic $\varepsilon$-globin gene expression at the fetal stage.

\section{MATERIALS AND METHODS}

\section{Preparation of nuclear extracts}

Nuclear extracts were prepared from the human fetal liver and brain at 4-5 months of gestation abortion according to the method of Gorski[6]. The protein concentration was determined by the Bradford's method[7].

\section{DNaseI footprinting assay}

The DNA fragment between -535bp and -177bp was prepared from $\mathrm{p} \varepsilon$ GLCAT-SV plasmid with restriction enzymes (XbaI and BamHI), labeled with $\gamma{ }_{-}^{32}$ p-ATP and digested with HincII. The probe (from -392 to -177bp) was used for DNaseI footprinting assay. According to the method describled by Berg et al[8], approximately $36 \mu \mathrm{g}$ of nuclear proteins were preincubated for $10 \mathrm{~min}$ on ice in binding buffer ( $10 \mathrm{~m} M$ Tris-HCl, $\mathrm{pH}$ 7.6, $100 \mathrm{~m} M \mathrm{KCl}, 1 \mathrm{~m} M \mathrm{MgCl}_{2}, 1 \mathrm{~m} M$ EDTA, 10 
$\mathrm{mMDTT}, 4 \%$ glycerol and $0.1 \%$ Triton X-100), followed by addition of DNA probe ( $\sim 5 \mathrm{fmol})$ and a further $20 \mathrm{~min}$ incubation. $1 \mu \mathrm{g}$ polyd (I-C) was added as a nonspecific competitor. DNaseI and $\mathrm{MgC1}_{2}$ (4 mM final concerntration) were added for $20 \sim 60 \mathrm{sec}$. Digested DNA was extracted with phenol, precipitated with enthanol and was resolved by $8 \%$ polyacrylamide gel. A+G ladder was prepared by using Maxam and Gilbert's method[9].

\section{Gel mobility shift assay and competition analysis}

Gel mobility shift assay was performed according to the method described by Strauss and Varshavsky[10]. Based on the result of DNaseI footprinting assay, the major protected region DNA fragment $(-278 b p \sim-235 b p)$ was synthesized and labeled with $\gamma_{-}{ }^{32}$ p-ATP as a probe. The reaction mixture $(25 \mu \mathrm{l})$ contained approximately $5 \mathrm{fmol}$ of labeled DNA probe, 3-5 $\mu \mathrm{g}$ of nuclear proteins and $1 \mu \mathrm{g}$ polyd (I-C) as a nonspecific competitor in the binding buffer $(10 \mathrm{~m} M$ Tris-HCl, $\mathrm{pH} 7.6$, $100 \mathrm{~m} M \mathrm{KCl}, 1 \mathrm{~m} M \mathrm{MgCl}_{2}, 1 \mathrm{~m} M$ EDTA, $10 \mathrm{~m} M$ DTT, $4 \%$ glycerol and $0.1 \%$ Triton X-100). These mixtures were incubated for $1 \mathrm{~h}$ on ice and analyzed with $4 \%$ nondenaturing polyacrylamide gel. Gel was dried and autoradiographed at $-20{ }^{\circ} \mathrm{C}$. In competitive gel mobility shift analysis, the synthetic oligonucleotides corresponding to the binding motifs of GATA-1 (5'GTTGCAGATAGACATT3') and YY-1 (5'CGACATTTTC3') were used as specific competitors.

\section{Southwestern blotting assay}

Southwestern blotting assay was carried out according to the method described by Erwei Gao et al[11]. Approximately $100 \mu \mathrm{g}$ of nuclear protein from the human fetal liver was separated by $12 \%$ SDS-polyacrylamide gel, transferred to a nitrocellulose filter (Schleicher and Schuell) in transfer buffer ( $50 \mathrm{~m} M$ Tris-HCl, $40 \mathrm{~m} M$ glycine, $0.04 \%$ SDS, $20 \%$ methanol) at $125 \mathrm{~mA}$ for $16 \mathrm{~h}$ at $4{ }^{\circ} \mathrm{C}$. After the transfer was completed, the filter was soaked in blocking buffer ( $50 \mathrm{~m} M$ Tris-HCl, $1 \mathrm{~m} M$ DTT, $5 \%$ Carnation non-fat milk powder, $5 \mu \mathrm{g} / \mathrm{ml}$ denatured and sonicated calf thymus DNA) at room temperature for $1 \mathrm{~h}$, then the filter was incubated in binding buffer $(50 \mathrm{~m} M$ Tris-HCl, $\mathrm{pH}$ 8.0, $50 \mathrm{~m} M \mathrm{NaCl}, 1 \mathrm{~m} M \mathrm{MgCl}_{2}, 1 \mathrm{~m} M$ EDTA, $1 \mathrm{~m} M$ DTT, $0.25 \%$ Carnation non-fat milk powder) containing $5 \times 10^{5} \mathrm{cpm} / \mathrm{ml}$ DNA probe labeled with $\gamma{ }_{-}^{32} \mathrm{p}$-ATP $(-278 \mathrm{bp} \sim-235 \mathrm{bp})$ at $4{ }^{\circ} \mathrm{C}$ for 3 h. The filter was washed four times ( $8 \mathrm{~min} / \mathrm{each}$ wash) at $4{ }^{\circ} \mathrm{C}$ with binding buffer and subjected to autoradiography.

\section{RESULTS}

\section{Identification of the binding site within the silencer element of the human $\varepsilon$-globin gene}

Previous studies have shown that the silencer between -392bp and -177bp upstream of the human $\varepsilon$-globin gene is indeed necessary for the complete stage-specific silencing of this gene during fetal and adult stages[5]. In order to investigate the molecular mechanism of this silencer, DNaseI footprinting assay was used to examine the binding site within this silencer region with the nuclear extract from the human fetal liver, in which the human embryonic $\varepsilon$-globin gene was completely silenced, however, the human fetal $\gamma$-globin genes were activated. In DNaseI footprinting assay, we found that a major protected region from $-278 \mathrm{bp}$ to $-235 \mathrm{bp}$ and a minor protected region from $-218 \mathrm{bp}$ to $-207 \mathrm{bp}$ within this silencer element could be observed (Fig 2, Lanes 5-8). The major protected region contains a sequence (from $-273 \mathrm{bp}$ to $-265 \mathrm{bp}$ ) with $88 \%$ homology to the binding site for the YY1 transcription factor[12], which can activate or repress transcription of viral and some eukaryotic genes[13, 14, 15]. Within this protected region an inverted repeat of a six-nucleotides 
DNA-protein interaction in the human $\varepsilon$-globin gene silencer

motif, which is homologous to the GATA-1 consensus sequence, can also be detected (Fig 2)[12].

Fig 2 DNaseI footprinting assay of the labeled DNA probe(from-392 to $177 \mathrm{bp}$ ) with the nuclear extract from human fetal liver at 4-5 months of gestation. Lane $1, \mathrm{~A}+\mathrm{G}$ ladder. Lanes 2, 3 and 4, labeled DNA fragment without nuclear extract $(0.5 \mu \mathrm{g}$ DNaseI for $20 \mathrm{~s}, 30 \mathrm{~s}$ and $40 \mathrm{~s}$ ). Lanes 5, 6, 7 and 8, labeled DNA fragment with $36 \mu \mathrm{g}$ nuclear extract $(0.5 \mu \mathrm{g}$ DNaseI for $20 \mathrm{~s}$, $30 \mathrm{~s}, 40 \mathrm{~s}$ and $60 \mathrm{~s})$. The box " indicates the binding site.

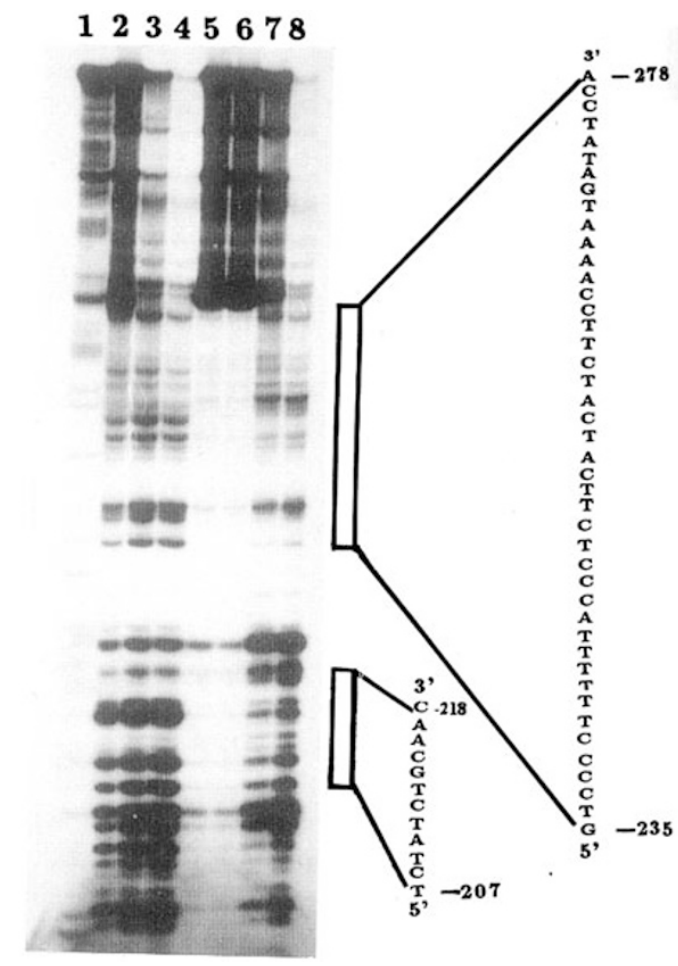

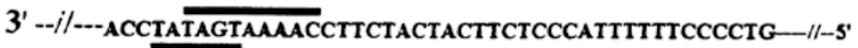
GATA-1

Characterization of trans-acting factors binding to the human $\varepsilon$-globin gene silencer

To characterize the nuclear proteins binding to the human $\varepsilon$-globin gene silencer, the gel mobility shift assay was carried out. The synthetic major protected region DNA fragment $(-278 b p \sim-235 b p)$ was used as a probe. It was incubated with the nuclear extracts from the human fetal liver and brain(as a nonerythroid control) at $4 \sim 5$ months of gestation. We found in the gel mobility shift assay that at least four shift bands (A, B, C and D) could be observed with the nuclear extract of the human fetal liver. The results demonstrated that shift bands A, B and D were common to those of the human fetal brain, however, band $\mathrm{C}$ was specific for the human fetal liver, indicating that band $\mathrm{C}$ was eryhroid-specific (Fig 3). We speculated that there were at least three nonerythroid trans-acting factors (shift bands A, B, D) and one erythroid-specific trans-acting factor (shift band $\mathrm{C}$ ) in the nuclear extract 
of the human fetal liver, which could specifically bind to the silencer region of human embryonic $\varepsilon$-globin gene, suggesting that these trans-acting factors might play an important role in silencing the human embryonic $\varepsilon$-globin gene expression during the fetal stage.

Fig 3. Gel mobility shift assay of the labeled DNA probe (from -278 to $235 \mathrm{bp}$ ) with the nuclear extracts from human fetal liver and brain at 4-5 months of gestation. Lane 1 , labeled DNA fragment without nuclear extract. Lanes 2 and 3, labeled DNA fragment with $3 \mu \mathrm{g}$ and $5 \mu \mathrm{g}$ of nuclear extract from the human fetal liver. Lanes 4 and 5, labeled DNA fragment with $3 \mu \mathrm{g}$ and $5 \mu \mathrm{g}$ of nuclear extract from the human fetal brain.

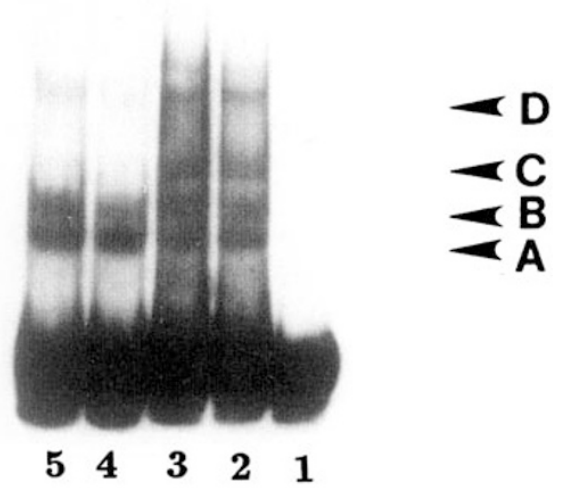

DNaseI footprinting assay has demonstrated that the major protected region ($278 \mathrm{bp}$ to $-235 \mathrm{bp}$ ) contains a GATA-1 binding motif and a YY-1 binding motif. It has been shown that GATA-1 is a $50 \mathrm{kD}$ erythroid-specific transcriptional factor, which acts as an activator and plays an important role in erythroid cell differentiation and embryonic development[16]. YY-1 is a $68 \mathrm{kD}$ ubiquitous transcriptional factor which mediates transcriptional repression and activation of viral and some eukaryotic genes[13, 14, 15]. Recently, Raich et al reported that GATA-1 and YY-1 were developmental repressors of the human $\varepsilon$-globin gene[17]. In order to determine the relationship between these four trans-acting factors and GATA-1 or YY-1, we synthesized two double-stranded oligonucleotides corresponding to the binding motifs of GATA-1 and YY-1 respectively as competitors, and the competitive gel mobility shift analysis was carried out. As shown in Fig 4, the shift bands(band A, B, C and D) couldn't be competed by GATA-1 and YY-1 binding motifs even at a 200-fold excess, implying that these trans-acting factors might be new regulatory proteins.

In order to define the molecular weights of these trans-acting factors identified above, Southwestern blotting assay was performed. As can be seen in Fig 5, we observed that there were at least four protein factors which could specifically bind to the DNA probe, and their molecular weights were near 32, 28, 26 and $22 \mathrm{kD}$ respectively. Our results further demonstrated that at least four protein factors might exist in the nuclear extract from the human fetal liver, which could specifically bind to the silencer element of the human $\varepsilon$-globin gene. To characterize further these trans-acting factors is well under way. 
DNA-protein interaction in the human $\varepsilon$-globin gene silencer

Fig 4. Competitive gel mobility shift analysis of the labeled DNA probe (from -278 to $-235 \mathrm{bp}$ ) with the nuclear extract from human fetal liver at 4-5 months of gestation and competitors (GATA-1 binding motif and YY-1 binding motif). Lane1, labeled DNA fragment without nuclear extract. Lanes 2 and 3, labeled DNA fragment with 3 and 5 $\mu \mathrm{g}$ nuclear extract. Lane 4 , labeled DNA fragment with $5 \mu \mathrm{g}$ nuclear extract, the unlabeled DNA fragment (-278bp $\sim-235 \mathrm{bp})$ was added as a competitor at 100 -fold molar excess. Lanes 5 and 6, labeled DNA fragment with $5 \mu \mathrm{g}$ nuclear extract,

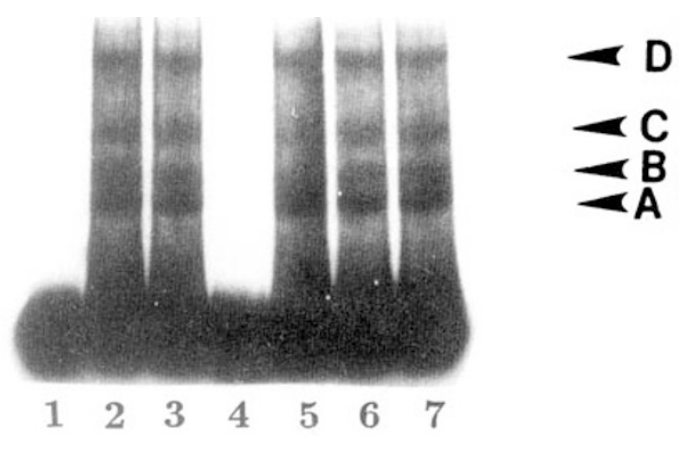
the unlabeled GATA-1 binding motif (5'GTTGCAGATAGACATT3') was added as a competitor at 100- and 200-fold molar excess, respectively. Lane 7, labeled DNA fragment with $5 \mu \mathrm{g}$ nuclear extract, the unlabeled YY-1 binding motif (5'CGACATTTTG3') was added as a competitor at 200 -fold molar excess.

Fig 5. Southwestern blotting assay. The nuclear extract from human fetal liver at 4-5 months of gestation KD was separated by $12 \%$ SDS-PAGE, transferred to a nitrocellulose filter and incubated with the labeled DNA fragment $(-278 b p \sim-235 \mathrm{bp})$. Protein - DNA interaction was analyzed by autoradiography.

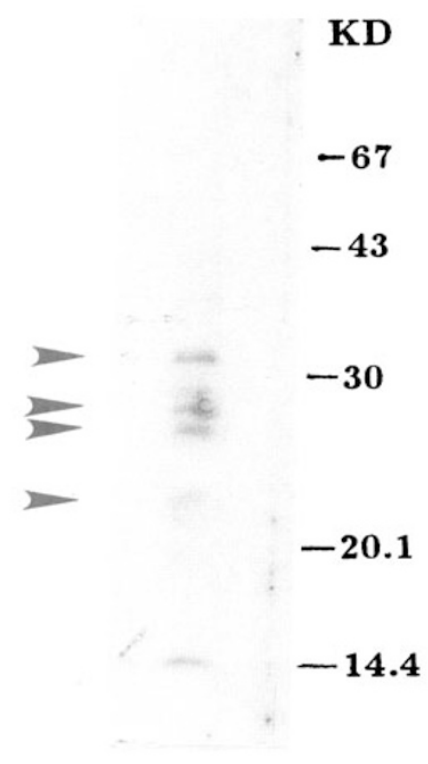

\section{DISCUSSION}

Erythroid differentiation during development is characterized by specific patterns of globin gene expression. The study of globin gene expression has served as an important paradigm for understanding tissue-specific and developmentally regulated transcription. The human $\beta$-like globin gene cluster contains five genes $(\varepsilon, \mathrm{G} r, \mathrm{~A} r \delta$, $\beta$ ), which are successively expressed as the site of erythropoiesis shifts during development. The $\varepsilon$-globin gene is expressed only in the blood island of the embryonic yolk sac, the two $r$-globin genes are expressed in the fetal liver and the $\delta, \beta$-globin genes 
are expressed mainly in adult bone marrow[1]. Activation and high level expression of the individual gene of the cluster is largely dependent on the locus control region (LCR), a distal erythroid-specific regulatory element located $6 \sim 20 \mathrm{~kb}$ upstream of the $\varepsilon$-globin gene that consists of a series of erythroid-specific DNaseI hypersensitive sites[18]. Recent studies on transgenic mice or differentiating embryoid bodies have shown that the human $\varepsilon$-globin gene, linked in cis with LCR sequence, is expressed in a developmentally appropriate manner which is independent of the presence of other globin genes within the locus, indicating that the developmental regulation of the $\varepsilon$-globin gene depends on sequences within the $\varepsilon$-globin gene itself[2, 3, 19, 20]. Initial evidence for sequences involved in the $\varepsilon$-globin gene silencing came from deletional analysis of the region located upstream from the $\varepsilon$-globin gene cap site. By transient transfection of deleted $\varepsilon$-globin constructs into HeLa and K562 cells, a transcription silencer was identified between -392bp and -177bp[4]. Deletion of this sequence results in the continued expression of the human $\varepsilon$-globin gene during late fetal and adult develapment in transgenic mice, suggesting that in vivo this silencer may play an important role in silencing the human embryonic $\varepsilon$-globin gene at these later development stages[5].

In order to investigate the regulatory role of this silencer element and to understand the molecular mechanism of the human $\varepsilon$-globin gene silencing, we have prepared the nuclear extract from the human fetal liver and focused on identifying and characterizing trans-acting factors which may mediate the function of this silencer in the human fetal liver. DNaseI footprinting assay indicated that the nuclear proteins isolated from human fetal liver were capable of binding to the silencer, particularly to a region between $-278 b p$ and $-235 b p$ within the silencer sequence. This protected region has also been observed with the nuclear protein from mouse fetal liver at day 18 of gestation[21], suggesting that the silencer activity of human $\varepsilon$-globin gene may be mediated by this region. Gel mobility shift assay further showed that there were at least three nonerythroid nuclear protein factors and one erythroid-specific nuclear protein factor in the human fetal liver, which could specifically bind to this silencer region.

As shown by DNaseI footprinting assay, the major protein binding region (between -278bp and -235bp) of the $\varepsilon$-silencer element contains the GATA-1 and YY-1 binding motifs. Raich et al observed in transgenic mice experiments that GATA-1 and YY-1 were developmental repressors of the human $\varepsilon$-globin gene[17]. However, our results from competitive gel mobility shift assay and Southwestern blotting assay demonstrate that these trans-acting factors identified in the human fetal liver differ from GATA-1 and YY-1, suggesting that these trans-acting factors may be new regulatory proteins and may play an important role in silencing the human embryonic $\varepsilon$-globin gene expression at the fetal stage through the interactions with the silencer element.

Taken together, the results presented here may provide some important clue to the molecular regulatory mechanism involved in the stage-specific silencing of hu- 
DNA-protein interaction in the human $\varepsilon$-globin gene silencer

man $\varepsilon$-globin gene during development.

\section{ACKNOWLEGEMENTS}

This project was supported by Chinese National Nature Science Foundation.

\section{REFERENCES}

[1] Karlsson S and Nienhuis AW. Developmental regulation oh human globin gene. Ann Rev Biochem 1985; 54:1071-108.

[2] Shih DM, Wall RJ and Shapiro ST. Developmentally regulated and erythroid-specific expression of the human embryonic globin gene in transgenic mice. Nucleic Acida Research 18, 5465-72.

[3] Raich N, Enver T, Nakamoto B et al. Autonomous development control of human embryonic globin gene switching in transgenic mice. Science 1990; 250:1147-9.

[4] Cao SH, Gutuman PD, Dave HPG et al. Identification of a transcriptional silencer in the 5' flanking region of the human $\varepsilon$-globin gene. Proc Natl Acad Sci USA 1989; 86:5306-9.

[5] Raich N, Papaynnopoulou T, Stamatoyannopoulos G et al. Demonstration of a human $\varepsilon$-globin gene silencer with studies in transgenic mice. Blood 1992; 79:861-4.

[6] Gorski K, Carneiro M and Schibler U, Tissue-specific in vitro transcription from the mouse albumin promoter. Cell 1986; 47:767-76.

[7] Bradford MM. A rapid and sensitive method for the quantitation of microgram guantities of protein utilizing the principle of protein-dye binding. Anal Biochem 1976; 72:248-54.

[8] Berg PE, Williams DM, Qian RL et al. A common protein to two silencers 5' the human $\beta$-globin gene. Nucleic Acid Research 1989; 17:8833-52.

[9] Maxam A and Gilbert W. Sequencing end-labeled DNA with base-specific chemical cleavages. Methods Enzymol 1980; 65:499-560.

[10] Strauss F and Varshavsky A. A protein binds to a satellite DNA repeat at three specific sites that would be brought into mutural proximity by DNA folding in the nucleosome. Cell 1984; 37:889-901.

[11] Erwei Gao, Joseph L Alcorn et al. Identification of enhancers in the 5'-flanking region of the rabbit surfactant protein A (SP-A) gene and characterization of their binding proteins. J Biol Chem 1993; 268:19697-709.

[12] Gumucio D, Heilsterlt Williamson H, Gray TA et al. Phylogenetic footprinting reveals a nuclear protein which binds to silencer sequences in the human $\gamma$-and $\varepsilon$-globin gene. Mol Cell Biol 1992; 12:4919-9.

[13] Shi Y, Seto E and Chang LS. Transcriptional repression by YY-1, a Human GLI-Kruppel-related protein, and relief of repression by adenovirus E1A protein. Cell 1991; 67:377-88.

[14] Kyoungsook P and Atchison M L. Isolation of a candidate repression/activator, NF-E1 (YY-1, d) that binds to the immunoglobulin $\mathrm{k} 3$ ' enhancer and the immunoglobulin heavy-chain $\mathrm{mE} 1$ site. Proc Natl Acad Sci USA 1991; 88:9804-8.

[15] Hariharan N, Kelley DE, Perry R P et al. d, a transcription factor that binds to downstream elements in several polymerase II promoters, is a functionally versatile zinc finger protein. Proc Natl Acad Sci USA 1991; 88:9799-803.

[16] Orkin SH. Regulation of globin gene expression in erythroid cell. Eur J Biochem 1995; 231:27181.

[17] Raich N, Clegg CH and Grofti J. GATA-1 and YY-1 are developmental repressors of the human $\varepsilon$-globin gene. EMBO J 1995; 14:801-9.

[18] Grosveld F, Blom van Assandelft G, Greaves D, et al. Position independent expression of the human beta globin gene in transgenic mice. Cell 1987: 51:975-85. 
Yah ZJ et al.

[19] Lindenbaum M H and Grosveld F. An in vitro globin gene switching model based on differentiated embryonic stem cell. Gene and Dev 1990; 4:2075-85.

[20] Shih DM, Wall RJ, Shapiro SG, et al. A 5' control region of the human $\varepsilon$-globin gene is sufficient for embryonic specificity in transgenic mice. J Biol Chem 1993; 268:3066-71.

[21] Yan Z J, Chen YD and Qian RL. Studies on DNA-protein interactions in the upstream regulatory region of the human $\varepsilon$-globin gene promoter. Cell Research 1996; 6:101-4.

Received 11-9-1997. Revised 10-10-1997. Accepted 17-10-1997. 